\title{
Performance of District Central Cooperative Banks in Maharashtra
}

\author{
S. R. Panchal ${ }^{*}$, R. B. Hile and S. B. Sapkal \\ Department of Agricultural Economics, MPKV, Rahuri (M.S), India \\ *Corresponding author
}

\section{A B S T R A C T}

\section{Keywords}

Branches,

Membership,

Share capital,

Reserve funds

Article Info

Accepted:

26 January 2021

Available Online:

10 February 2021
The present study has been undertaken to examine the retrospects and prospects of DCCBs in Maharashtra. The attempt has been made to examine the growth performance of various financial indicators. The study is based on secondary data obtained from 30 DCCBs in Maharashtra for the period of past 32 years i .e. from 1985-86 to 2016-17. The rates of compound growth were estimated for three periods Viz., Period I i.e. 1985-86 to 1994-95, period II i.e. $1995-96$ to $2016-17$ and period III i.e. $1985-86$ to $2016-17$. The regionwise coefficient of Variation (CV) was workout and studied. The performance of DCCBs based on number of branches indicated that the performance of DCCBs in respect of branch expansion was satisfactory in the State. The annual rate of compound growth in number of branches of DCCBs in the State as a whole was significant during the entire period. The growth in total membership was mainly attributed to positive growth in PACS membership. The increase in share capital of DCCBs in Maharashtra over the years was mainly due to the increase in number of members and increased contribution of PACS to the share capital. The significant growth in total reserve funds was possible mainly because of a continuous flow of credit during the period under study.

\section{Introduction}

The word co-operation is derived from the Latin word "cooperate" and its elementary sense it simple means 'working together'. The principle of co-operation is as old as human society. A co-operative bank is a financial entity which belongs to its member's owners and the customers of their banks. Agriculture sector plays a strategic role in the process of economic development. Co-operative movement in Maharashtra has been a pioneering sector of the co-operative movement in the country.
Thereafter, co-operative began to strike roots Bombay state was the first to give the lead with an Act of 1925. The first co-operative sugar factory was started in Maharashtra at Pravaranagar in 1948. Cooperation is no way new to India it has been known and practiced in this country since time Immemorial.

The growth of modern movement of cooperatives is 100 years old; beginning with the enactment Co-operative Credit Societies Act on $25^{\text {th }}$ March, 1904. The main function of DCCBs is to finance the primary agricultural credit societies. They link between SCBs and PACSs to provide credit to 
both farmers and other beneficiaries. They also mobilize the savings from different groups of the society (both urban and rural areas) by offering various deposit schemes. They also provide other banking facilities like locker facility, cheque facility, transfer of funds, payment of bills etc.

The success of co-operative credit structure depends to a very large extent on the working of the DCCBs these banks not only safeguard the interest of the PACS but also various other types of credit and non- credit societies in the district. Hence, there is a need for the existence of a strong and good working District Central Co-operative Bank at the district level. Such a strong bank would act as a balancing center by drawing surplus funds from the surplus societies and by providing funds to the deficit societies.

The main objectives of the study include to study the performance of DCCBs in Maharashtra.

\section{Materials and Methods}

Desired results from any scientific study could be obtained only after planning and adoption appropriate methods and procedures during the investigation.

The main purpose of the present study was to analyze and compare the performance of the DCCBs in Maharashtra during the period of last 32 years i.e. from 1985-86 to 2016-17.

\section{Data requirement and sources of data}

Since the investigations based on macro level data, an attempt has been made to estimate region wise and period wise growth rates of performance of different indicators in DCC banks at Maharashtra over a period of last 32 years from 1985-86 to 2016-17. The time series data was used for analysis of the various aspects of the study are as follows.

1. The time series data on various selected indicators were obtained from the published data of NBFSCOB (Basic data on performance of District Central Cooperative Banks from the period 1985-86 to 2016-17) and annual reports of DCCBs to workout various performance indicators and trends in advances.

2. The district wise report on potential linked credit plans from the years 1985-86 to 2016-17 for Maharashtra were secured form NABARD office, Pune and obtained data used to workout purpose wise lending activities and per cent share of DCCBs in total credit disbursement.

Meaning of terms and concepts used in the study

\section{Membership}

Membership of DCCBs is open to all individual farmers. Primary agricultural credit societies, Marketing co-operative societies, consumer store and farming societies etc.

\section{Share capital}

Share capital is one of the important sources of funds of the DCCBs; Member societies and individuals are the main sources of share capital.

\section{Reserve finds}

Reserve funds of DCCBs include statutory reserve fund means the amount of liquid assets that DCCBs hold in order to protection against a substantial. Agricultural stabilization fund and other reserves include building funds, depreciation fund and educational tour funds. 


\section{Tabular analysis}

Simple tabular analysis was employed to evaluate the performance of District Central Co-operative Banks amongst different regions and over the period of time in Maharashtra. The following composition proportions and ratios of various cooperative performance indicators were calculated for each region and the state as a whole for period from 1985-86 to 2016-17.

\section{Physical indicators}

Number of branches (Nos.) 2. Number of members

\section{Financial Indicators}

Share capital (In Lakhs) 2. Reserve funds (In Lakhs)

\section{Results and Discussion}

Region wise and period wise performance of DCCBs in Maharashtra During 1985-86 to 2016-17

The region wise and period wise performance of DCCBs during 1985-86 to 2016-17 was studied for different indicators. The details of the analysis are presented as under.

\section{Number of branches}

The information on growth in number of branches of DCCBs in Maharashtra is presented in Table 1. It can be observed from the table the Western Maharashtra region occupied dominant place in the state by covering 50 per cent of the branches during the base years, middle years and the terminal years of the study. The total number of branches of the DCCBs has increased from 2225 in 1985-86 in base years, 3339 in middle years in 1995-96 and 3729 in 2016-17 i.e. by
67.59 per cent. The region wise performance of DCCBs in respect of number of branches showed highest growth in Konkan region $(105.75 \%)$ followed by Western Maharashtra $(81.70 \%)$, Vidarbha $(43.57 \%)$ and Marathwada (42.41\%). It looks that the performance of DCCBs in respect of branch expansion was satisfactory in the state. The annual rate of compound growth in number of branches of DCCBs in the state as a whole was 1.08 per cent, which was significant during the entire period under study. The region wise growth shows that the branches of DCCBs in Konkan region had significantly increased at the rate of 2.34 per cent per annum followed by Western Maharashtra $(1.29 \%)$, Vidarbha $(0.78 \%)$ and Marathwada $(0.32 \%)$ which is non significant growth during whole period under study.

Period I (1985-86 to 1994-95) was characterized by satisfactory performance of branch expansion in all the regions and the state as a whole owing to the newly formed four new DCCBs (Jalna, Latur, Sindhudurg and Gadchiroli) in 1983-84.

\section{Growth in membership}

Region wise and period wise growth in membership of DCCBs in Maharashtra during 1985-86 to 2016-17 is presented in Table 2. It can be revealed from table the Western Maharashtra region occupies a conspicuous position in the state with more than 50 per cent of the total membership during both years. Moreover, there was a steady increase in the total membership of DCCBs in Maharashtra during the period. The number of members had increased from 70726 in 198586, 91257 in 1995-96 and 130586 in 2016-17 i.e. by $(84.90 \%)$ over the base years. The maximum increase in the total membership was noticed in Konkan region (185.10\%) followed by Marathwada (91.09\%), Western Maharashtra $(77.25 \%)$ and Vidarbha region 
$(27.63 \%)$. This indicates that the satisfactory performance of DCCBs in respect of expansion and coverage.

The growth in membership of DCCBs in Maharashtra state as a whole witnessed a significant positive trend with annual rate of compound growth being 1.97 per cent during the entire period.

The regional comparison reveals that the annual rate of compound growth in total membership of DCCBs was positive and significant with high magnitudes in Konkan region (3.1\%) followed Western Maharashtra $(1.98 \%)$, Marathwada $(1.97 \%)$ and with a low magnitude in Vidarbha region $(0.82 \%)$ during the whole period under study.

\section{Growth in share capital}

The detail information of share capital position of DCCBs in different regions of the Maharashtra state during 1985-86, 1995-96 and 2016-17 is presented in Table 3.

The results revealed that the total share capital of the DCCBs in Maharashtra has steadily increased from ₹ 8206.29 lakhs in 1985-86 to ₹ 28015 lakhs in 1995-96 and 295681 lakhs in 2016-17.

Region wise trend showed the highest growth in total share capital in Vidarbha region $(4091.78 \%)$ followed by Konkan (3672.72 $\%)$, Western Maharashtra (3540.95 \%) and Marathwada (2697.65\%) over the base years 1985-86. It was mainly due to the existence of four new DCCBs and thereby increases in membership and disbursement of loans.

The DCCBs in Western Maharashtra region had maintained top position with respect to total share capital throughout the period of study. Out of total share capital of DCCBs in the state as a whole, Western Maharashtra region alone shared more than 50 per cent during three years. The total share capital of DCCBs in Maharashtra state as a whole, registered highly significant compound growth rate of 1.08 per cent per annum during the entire period.

\section{Growth in reserve fund}

The detailed position of reserve funds of DCCBs in the state is depicted in Table 4.

The reserve fund of the DCCBs has witnessed a steady growth over a period. It can be observed from the table; the reserve funds of DCCBs in the state had increased from ₹ 9146.47 lakhs in 1985-86 to 32228 lakhs in 1995-96 and 1037924 lakhs in 2016-17 and had registered an impressive increase of more than 11 times over the base years. As regards to the region wise trend, the total reserve funds of DCCBs in Konkan region registered a higher growth (15568\%) followed by Marathwada (14103.17 \%), Western Maharashtra (9538.84\%) and Vidarbha (9931.53\%) over the base years of 1985-86.

In the size of total reserve funds of DCCBs in the State, Western Maharashtra region had a lion's share, which was 50.25 per cent in 1985-86, which subsequently declined to 44.41per cent in $1995-96$ to 42.67 per cent in 2016-17.

For the State as a whole, the reserve funds showed a significant growth of 18.27 per cent per annum during the entire period. Amongst the regions, the Marathwada region had registered maximum compound growth rate of 19.42 per cent followed by Vidarbha $(19.05 \%)$, Konkan $(18.02 \%)$ and Western Maharashtra (17.59 \%). The significant growth in total reserve funds was possible mainly because of a continuous flow of credit during the period under study. 
Table.1 Growth in number of branches in Maharashtra (Numbers)

\begin{tabular}{|c|c|c|c|c|c|c|c|c|c|c|}
\hline \multirow{3}{*}{$\begin{array}{l}\text { Sr. } \\
\text { No }\end{array}$} & \multirow[t]{3}{*}{ Region } & \multicolumn{3}{|c|}{ Number of branches } & \multicolumn{3}{|c|}{ Percentage change } & \multicolumn{3}{|c|}{ Compound Annual Growth Rate (\%) } \\
\hline & & 1985-86 & 1995-96 & 2016-17 & Period I & Period II & $\begin{array}{l}\text { Overall } \\
\text { Period }\end{array}$ & Period I & Period II & $\begin{array}{l}\text { Overall } \\
\text { Period }\end{array}$ \\
\hline & & & & & $\begin{array}{c}\text { 1985-86 } \\
\text { To } \\
\text { 1994-95 }\end{array}$ & $\begin{array}{c}\text { 1995-96 } \\
\text { To } \\
\text { 2016-17 }\end{array}$ & $\begin{array}{c}\text { 1985-86 } \\
\text { To } \\
\text { 2016-17 }\end{array}$ & $\begin{array}{c}\text { 1985-86 } \\
\text { To } \\
\text { 1994-95 }\end{array}$ & $\begin{array}{c}\text { 1995-96 } \\
\text { To } \\
\text { 2016-17 }\end{array}$ & $\begin{array}{c}\text { 1985-86 } \\
\text { To } \\
\text { 2016-17 }\end{array}$ \\
\hline 1 & Konkan & $\begin{array}{c}191 \\
(8.58)\end{array}$ & $\begin{array}{c}245 \\
(7.34)\end{array}$ & $\begin{array}{c}393 \\
(10.54)\end{array}$ & 28.27 & 60.40 & 105.75 & $3.08 * * *$ & $1.9 * * *$ & $2.34 * * *$ \\
\hline 2 & Western Maharashtra & $\begin{array}{c}1104 \\
(49.62)\end{array}$ & $\begin{array}{c}1801 \\
(53.94)\end{array}$ & $\begin{array}{c}2006 \\
(53.79)\end{array}$ & 63.13 & 11.38 & 81.70 & $5.02 * * *$ & 0.51 & $1.29 * * *$ \\
\hline 3 & Marathwada & $\begin{array}{c}455 \\
(20.45)\end{array}$ & $\begin{array}{c}696 \\
(20.84)\end{array}$ & $\begin{array}{c}648 \\
(17.38)\end{array}$ & 52.96 & -6.89 & 42.41 & $5.99 * * *$ & $-1.4 * * *$ & 0.32 \\
\hline 4 & Vidarbha & $\begin{array}{c}475 \\
(21.35)\end{array}$ & $\begin{array}{c}597 \\
(17.88)\end{array}$ & $\begin{array}{c}682 \\
(18.29)\end{array}$ & 25.68 & 14.23 & 43.57 & $2.4 * *$ & -0.15 & $\mathbf{0 . 7 8} * * *$ \\
\hline 5 & Maharashtra & $\begin{array}{c}2225 \\
(100.00)\end{array}$ & $\begin{array}{c}3339 \\
(\mathbf{1 0 0 . 0 0})\end{array}$ & $\begin{array}{c}3729 \\
(\mathbf{1 0 0 . 0 0})\end{array}$ & 50.06 & 11.68 & 67.69 & $4.57 * * *$ & 0.07 & $1.08 * * *$ \\
\hline
\end{tabular}

(Figures in parentheses are the percentage to the total)

Note: $* * *, * *$ and $*$ indicate significance at 1,5 and 10 per cent level, respectively

Table. 2 Growth in membership of DCCBs in Maharashtra (Numbers)

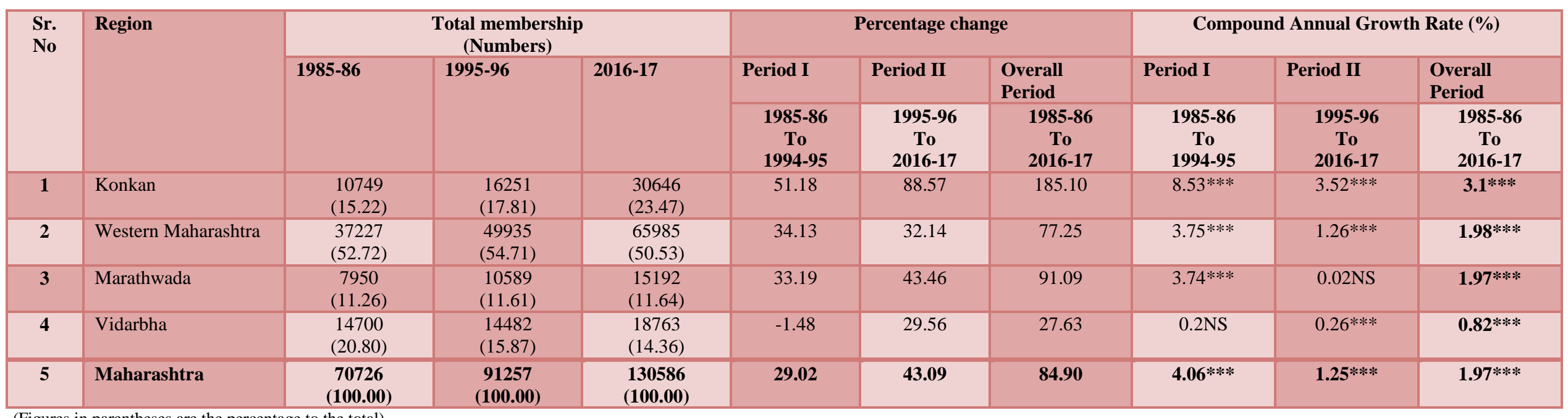

(Figures in parentheses are the percentage to the total)

Note: $* * *, * *$ and $*$ indicate significance at 1,5 and 10 per cent level, respectively 
Table.3 Growth in share capital of DCCBs in Maharashtra (lakh)

\begin{tabular}{|c|c|c|c|c|c|c|c|c|c|c|}
\hline \multirow{3}{*}{$\begin{array}{l}\text { Sr. } \\
\text { No }\end{array}$} & \multirow[t]{3}{*}{ Region } & \multicolumn{3}{|c|}{ Total share capital } & \multicolumn{3}{|c|}{ Percentage change } & \multicolumn{3}{|c|}{ Compound Annual Growth Rate (\%) } \\
\hline & & 1985-86 & $1995-96$ & 2016-17 & Period I & Period II & $\begin{array}{l}\text { Overall } \\
\text { Period }\end{array}$ & Period I & Period II & $\begin{array}{l}\text { Overall } \\
\text { Period }\end{array}$ \\
\hline & & & & & $\begin{array}{c}\text { 1985-86 } \\
\text { To } \\
\text { 1994-95 }\end{array}$ & $\begin{array}{c}\text { 1995-96 } \\
\text { To } \\
\text { 2016-17 }\end{array}$ & $\begin{array}{c}\text { 1985-86 } \\
\text { To } \\
\text { 2016-17 }\end{array}$ & $\begin{array}{c}\text { 1985-86 } \\
\text { To } \\
\text { 1994-95 }\end{array}$ & $\begin{array}{c}\text { 1995-96 } \\
\text { To } \\
\text { 2016-17 }\end{array}$ & $\begin{array}{c}\text { 1985-86 } \\
\text { To } \\
\text { 2016-17 }\end{array}$ \\
\hline 1 & Konkan & $\begin{array}{c}642.48 \\
(7.82) \\
\end{array}$ & $\begin{array}{c}3008 \\
(10.74)\end{array}$ & $\begin{array}{l}24239 \\
(8.20)\end{array}$ & 368.18 & 705.81 & 3672.72 & $3.08 * * *$ & $1.9 * * *$ & $2.34 * * *$ \\
\hline 2 & Western Maharashtra & $\begin{array}{c}4388.38 \\
(53.48)\end{array}$ & $\begin{array}{c}14527 \\
(51.86)\end{array}$ & $\begin{array}{l}159779 \\
(54.04)\end{array}$ & 231.03 & 998.87 & 3540.95 & $5.02 * * *$ & 0.51 & $1.29 * * *$ \\
\hline 3 & Marathwada & $\begin{array}{l}1538.18 \\
(18.74)\end{array}$ & $\begin{array}{c}6337 \\
(22.62)\end{array}$ & $\begin{array}{c}43033 \\
(14.55)\end{array}$ & 311.98 & 579.07 & 2697.65 & $5.99 * * *$ & $-1.4 * * *$ & 0.32 \\
\hline 4 & Vidarbha & $\begin{array}{c}1637.25 \\
(19.96)\end{array}$ & $\begin{array}{c}4143 \\
(14.78)\end{array}$ & $\begin{array}{c}68630 \\
(23.21)\end{array}$ & 153.06 & 1556.52 & 4091.78 & $2.4 * *$ & -0.15 & $0.78 * * *$ \\
\hline 5 & Maharashtra & $\begin{array}{l}8206.29 \\
(100.00)\end{array}$ & $\begin{array}{c}28015 \\
(100.00)\end{array}$ & $\begin{array}{c}295681 \\
(100.00)\end{array}$ & 241.38 & 955.43 & 3503.10 & $4.57 * * *$ & 0.07 & $1.08 * * * *$ \\
\hline
\end{tabular}

(Figures in parentheses are the percentage to the total)

Note: $* * *, * *$ and $*$ indicate significance at 1,5 and 10 per cent level, respectively

Table.4 Growth in reserve funds of DCCBs in Maharashtra

\begin{tabular}{|c|c|c|c|c|c|c|c|c|c|c|}
\hline \multirow[t]{3}{*}{$\begin{array}{l}\text { Sr. } \\
\text { No }\end{array}$} & \multirow[t]{3}{*}{ Region } & \multicolumn{3}{|c|}{$\begin{array}{l}\text { Total membership } \\
\text { (Numbers) }\end{array}$} & \multicolumn{3}{|c|}{ Percentage change } & \multicolumn{3}{|c|}{ Compound Annual Growth Rate (\%) } \\
\hline & & \multirow[t]{2}{*}{ 1985-86 } & \multirow[t]{2}{*}{$1995-96$} & \multirow[t]{2}{*}{ 2016-17 } & Period I & Period II & $\begin{array}{l}\text { Overall } \\
\text { Period }\end{array}$ & Period I & Period II & $\begin{array}{l}\text { Overall } \\
\text { Period }\end{array}$ \\
\hline & & & & & $\begin{array}{c}\text { 1985-86 } \\
\text { To } \\
1994-95\end{array}$ & $\begin{array}{c}\text { 1995-96 } \\
\text { To } \\
\text { 2016-17 }\end{array}$ & $\begin{array}{c}\text { 1985-86 } \\
\text { To } \\
\text { 2016-17 }\end{array}$ & $\begin{array}{c}\text { 1985-86 } \\
\text { To } \\
\text { 1994-95 }\end{array}$ & $\begin{array}{c}\text { 1995-96 } \\
\text { To } \\
\text { 2016-17 }\end{array}$ & $\begin{array}{c}\text { 1985-86 } \\
\text { To } \\
\text { 2016-17 }\end{array}$ \\
\hline 1 & Konkan & $\begin{array}{l}1438.58 \\
(15.73)\end{array}$ & $\begin{array}{c}10468 \\
(32.49)\end{array}$ & $\begin{array}{l}225403 \\
(21.72)\end{array}$ & 627.66 & 2053.25 & 15568.43 & $26.35 * * *$ & $13.02 * * *$ & $18.02 * * *$ \\
\hline 3 & Marathwada & $\begin{array}{l}1374.77 \\
(15.03)\end{array}$ & $\begin{array}{c}3884 \\
(12.05)\end{array}$ & $\begin{array}{l}195261 \\
(18.82)\end{array}$ & 182.51 & 4927.31 & 14103.17 & $11.93 * * *$ & $13.37 * * *$ & $19.42 * * *$ \\
\hline 4 & Vidarbha & $\begin{array}{l}1737.6 \\
(18.99)\end{array}$ & $\begin{array}{l}3563 \\
(11.05)\end{array}$ & $\begin{array}{l}174308 \\
(16.79)\end{array}$ & 105.05 & 4792.16 & 9931.53 & $8.93 * * *$ & $14.38 * * *$ & $19.05 * * *$ \\
\hline 5 & Maharashtra & $\begin{array}{l}9146.47 \\
(100.00)\end{array}$ & $\begin{array}{c}32228 \\
(\mathbf{1 0 0 . 0 0})\end{array}$ & $\begin{array}{l}1037924 \\
(100.00)\end{array}$ & 252.35 & 3120.56 & 11247.80 & $15.59 * * *$ & $13.86 * * *$ & $18.27 * * *$ \\
\hline
\end{tabular}

(Figures in parentheses are the percentage to the total)

Note: $* * * * *$ and $*$ indicate significance at 1,5 and 10 per cent level, respectively 


\section{Conclusions and policy implications}

Study as whole the performance of DCCBs in terms of network coverage was satisfactory as the number of offices and membership had increased during the study period.

A significant increase in the total share capital, reserve fund, during the study period indicated the financial soundness of DCCBs in Maharashtra state.

The policy implications based on the conclusions of the present study could be listed as under.

The DCCBs are required to be operated more transparently to minimize the level of percentage of NPAs as compared with international standards and disbursement may be strictly based up on repaying capacity of borrowers, technical efficiency and economical soundness of the societies.
Due importance is required to be given to borrower members which will lead to increase in the share capital and loan disbursement for agricultural purpose.

\section{References}

Jadhav, A.J. 2009. Performance analysis of Pune District Central Co-operative Bank in Maharashtra. Unpublished M.Sc. thesis submitted to Mahatma Phule Krishi Vidyapeeth, Rahuri, Maharashtra.

Hiremath, B. and Bannur, M. 2014. Studied financial performance of Bijapur district Central Co-operative Bank Ltd., Bijapur, Karnataka State, India. International Journal of Research in Computer Science and Management, 1(1): 40-43.

Hooda, V. and Chahal, S.S. 2010. Performance of Primary Agricultural credit societies in India: an appraisal. Indian Cooperative Review, 48(2); 77-84.

\section{How to cite this article:}

Panchal, S. R., R. B. Hile and Sapkal, S. B. 2021. Performance of District Central Cooperative Banks in Maharashtra. Int.J.Curr.Microbiol.App.Sci. 10(02): 3400-3406.

doi: https://doi.org/10.20546/ijcmas.2021.1002.375 